\title{
Evaluating the Impact of Vertical Greenery System on Cooling Effect on High Rise Buildings and Surroundings: A Review
}

\author{
Badrulzaman Jaafar', Ismail Said ${ }^{2}$, Mohd Hisyam Rasidi ${ }^{3}$ \\ ${ }^{1}$ Green Innovation Research Group, Universiti Teknologi Malaysia, \\ 81310 Skudai, Johor, Malaysia \\ 2 Department of Landscape Architecture, Faculty of Built Environment, \\ Universiti Teknologi Malaysia, 81310, Skudai, Johor, Malaysia \\ ${ }^{3}$ Departmen t of Landscape Architecture, Faculty of Built Environ ment, \\ Universiti Teknologi Malaysia, 81310, Skudai, Johor, Malaysia \\ Badrazj@gmail.com
}

\begin{abstract}
Rapid urbanization and the concern for climate change have led to a growing trend to bring nature into the cities. Due to artificial urbanization, urban heat islands have become a serious problem. Greenery is expected to be an effective countermeasure, and much research is available regarding green roofs, green walls, street trees and parks. The intent of this paper is to present a synthesis of the literature review on the design and technology for cooling of building and surroundings by using vertical greenery system. Effect of design parameters on building microclimate and the applicable cooling technologies are discussed.
\end{abstract}

Keywords: Vertical greenery system, cooling effect, temperature reduction, humidity

\section{Introduction}

In today's world, the rapid pace of urbanization and the growing concern for climate change have led to the increasing trend of bringing nature back into cities (Chiang and Tan, 2009). Removal of greenery and replaced them with build ings and paved streets increase the surface radiation and air temperature that result to drier and hotter environment for urban cities compared to the rural areas. Increased air temperature can be expected to be particularly problematic in urban areas, where temperatures already tend to be a few degrees warmer than the surrounding countryside. This difference in temperature between urban and rural areas has been called the 'urban heat island effect'. Urbanization leads to change in the absorption and reflection of solar radiation, and thus the surface energy balance.

The heat island phenomenon may occur during the day or night. A report by Givoni (1998) mentioned that the largest elevation of the urban temperature occur during clear and still-air nights. Under these conditions, temperature elevations of about $3-5^{\circ} \mathrm{C}$ are common, but elevations of about $8-10^{\circ} \mathrm{C}$ were also observed. Today, the majority of cities are around $2^{\circ} \mathrm{C}$ warmer than rural areas and commercial and high density residential areas are hotter by 5 to $7^{\circ} \mathrm{C}$ (Bonan, 2002). Man is altering the climate, which affects him and his activities through the building of cities. He has altered the climate by changing the physical surface of the land and producing significant amount of heat and pollutants. 
As cities grow, buildings and paved surfaces replace the natural landscape. Hard inert surfaces absorb heat, causing their temperature to rise steadily with increasing exposure. Dark colored surfaces like roofs, roads and parking lots absorb the greatest a mount of heat. Large masses of tarmac, concrete and steel buildings absorb and store large amounts of heat, which in turn radiated into the surroundings. Urban greenery has been attracting an increased attention as the mitigation against urban thermal environment. In order to establish a feasible greening plan, however, it is strongly needed to understand the potential spaces for greening in the substantial urbanized areas. Thus, greenery has become a key element of urban transformation and the exterior surfaces of buildings have been deemed to hold vast opportunities for the insertion of greenery into urban-spaces; planting on roofs and walls has since become one of the most innovative and rapidly developing features of city planning, architecture and ecological landscaping.

Greenery can be used as a tool for mitigating the Urban Heat Island (UHI) effect; directly by shading heat-absorbing surfaces and indirectly through evapotranspiration cooling (McPherson, 1994). UHI describes the built up areas that are hotter than nearby rural areas. This effect can be felt in urban areas where buildings, roads and other infrastructure replace vast vegetative land areas that were once moist and permeable with hard surfaces that are dry and impermeable. The annual mean air temperature of city with 1 million people or more can be 1 to $3^{0} \mathrm{C}$ warmer than its surroundings (US EPA, 2008). Hence, greening of the facade of building walls, known as vertical greenery systems (VGSs), has yet to be fully explored and exploited. Simply due to the sheer amount of building walls, the widespread use of vertical greenery systems not only represents a great potential in mitigating the UHI effect through evapotranspiration and shading, it is also a highly impactful way of transforming the urban landscape (Wong et al. 2010). Concisely, in this paper is a review that has been made of the essence, advantages, techniques and types of vertical greenery system research as part of a sustainable strategy for the urban environment.

\section{Materials and Method}

\subsection{Literature Overview}

\subsubsection{Definition of vertical greenery system}

The meaning of the term vertical greenery has gathered a divergence of opinions (Table 2). According to Chiang (2009), vertical greenery as greenery integrated into built forms in the city includes balcony gardens, sky terraces and green roofs. Meanwhile, Cheng (2010) gave his definition on vertical greenery as an alternative to roof greenery in a city composed of tower blocks which have high wall to roof ratio, and consequently large potential surface area for greening. Moreover, facade walls, unlike rooftops, usually have no insulation layer against solar heat. The community will benefit if a vegetated cladding on building can exhibit the efficacy of a green roof.

However Peck et al. (1999) and Bass and Baskaran (2003) defined vertical greenery system as a vertical gardening which comprehensive term referring to any manner in which plants can be grown on, up, or against the façade of building or feature walls such as a vine, as part of a window shade, as a balcony garden, or in a vertical hydroponic system. Traditionally, vertical greenery commonly involved climbing plants with adventitious, self- 
clinging roots growing up directly on coarse building surface, twining plants growing up trellis and pergolas or individual plants growing within the crevices of stacked rocks.

\subsubsection{Typologies of Vertical Greenery Systems}

Generally, the various vertical greenery system fall into two broad categories such as "support" and "carrier". The support systems are designed to guide plants up on the vertical surface, while carrier systems are designed to contain the media for planting on the vertical surface. The selection of systems is guided by the type of plants to be planted. The support systems, also commonly termed as "green facades", allow climbing plants and cascading groundcovers to grow up the façade on specially designed support structures. In contrast, carrier systems are able to host a greater diversify of plants, including groundco vers, shrubs, ferns, grasses, sedges and even mosses. Such systems are commonly termed "living wall" (Figure 1).

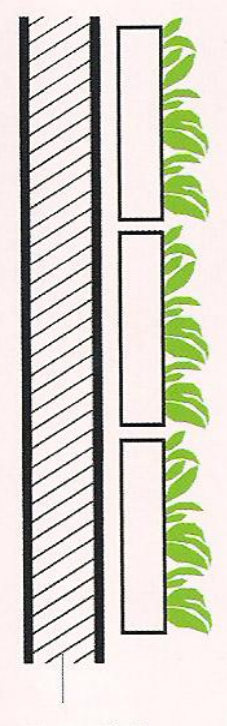

Vertical Greenery 'Carrier' System

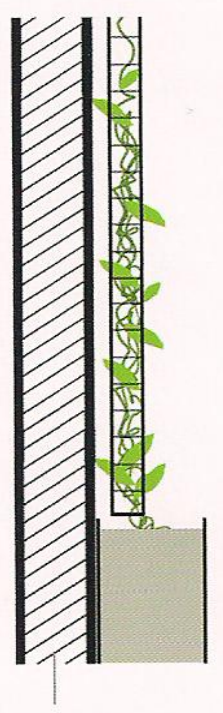

Vertical Greenery 'Support' System

Figure 1. The difference between "support" and "carrier" in the vertical greenery system (Source: Chiang K and Tan A, 2009) 


\section{Tabel 1. Definitions of vertical greenery system according to researchers}

\begin{tabular}{|c|c|c|}
\hline Terminology & Citation & Description \\
\hline Vertical garden & $\begin{array}{l}\text { Peck S.W et al. (1999), } \\
\text { Bass B. and Baskaran B. } \\
\text { (2001), Alexandri and } \\
\text { Jones (2008), Perini et al. } \\
\text { (2011) }\end{array}$ & $\begin{array}{l}\text { Vertical garden is a descriptive term used to refer to all } \\
\text { forms of plant surface of the wall. It is used to } \\
\text { determine the growing plants, up, or on the façade of } \\
\text { buildings. }\end{array}$ \\
\hline Green facade & $\begin{array}{l}\text { Green Roofs for Healthy } \\
\text { Cities GRHC (2008), } \\
\text { Chiang and Tan (2009) }\end{array}$ & $\begin{array}{l}\text { Green wall system in which climbing plants or } \\
\text { cascading groundcovers are trained to cover specially } \\
\text { designed supporting structures. Rooted at the base of } \\
\text { these structures, in the ground, in intermediate planters } \\
\text { or even on rooftops, the plants typically take 3-5 years } \\
\text { before achieving full coverage. }\end{array}$ \\
\hline Green wall & $\begin{array}{l}\text { Green Roofs for Healthy } \\
\text { Cities GRHC (2008), }\end{array}$ & $\begin{array}{l}\text { It is also referred as the 'vertical garden', is a } \\
\text { descriptive term used to refer to all forms of vegetation } \\
\text { surface. Green wall technologies can be divided into two } \\
\text { main categories such as green facades and living walls. }\end{array}$ \\
\hline Living wall & $\begin{array}{l}\text { Green Roofs for Healthy } \\
\text { Cities, GRHC (2008), } \\
\text { Birkeland (2009), Chiang } \\
\text { and Tan }(2009)\end{array}$ & $\begin{array}{l}\text { It is consists of prevegetated panels, vertical modules or } \\
\text { planted blankets that are fixed vertically to a structural } \\
\text { wall or frame. These panels can be made of plastic, } \\
\text { expanded polystyrene,synthetic fabric, clay, metal, and } \\
\text { concrete. }\end{array}$ \\
\hline Green space wall & Birkeland (2008) & $\begin{array}{l}\text { It is refered to an ecosphere that doubles as an exterior } \\
\text { wall or mixed interior/exterior spaces in new } \\
\text { development. These walls can create multiple, } \\
\text { synergistic uses of space such as generate clean energy, } \\
\text { air, water, food, soil and providing social space. }\end{array}$ \\
\hline Green scaffolding & Birkeland (2008) & $\begin{array}{l}\text { It is applies mainly to eco-retrofitting. It essentially } \\
\text { wraps a light weight structure around the exterior of } \\
\text { existing buildings to provide the full range of climatic } \\
\text { and ecosystem functions such as vertical landscapes for } \\
\text { water and air purification. }\end{array}$ \\
\hline Biofacade wall & Abdul et al. (2011) & $\begin{array}{l}\text { It is referred to green facade as a support system refers } \\
\text { to vegetation which was guided to climb up through the } \\
\text { structure like wires or cables. }\end{array}$ \\
\hline $\begin{array}{l}\text { Vertical Greenery } \\
\text { System }\end{array}$ & $\begin{array}{l}\text { Wong et al. (2009), Cheng } \\
\text { et al. (2010), Wong et al. } \\
(2010)\end{array}$ & $\begin{array}{l}\text { It is referred to comprehensive term referring to any } \\
\text { manner in which plants can be grown on, up, or against } \\
\text { the façade of building or feature walls such as a vine, as } \\
\text { part of a window shade, as a balcony garden, or in a } \\
\text { vertical hydroponic system. }\end{array}$ \\
\hline
\end{tabular}

(Source: Badrul, 2011) 


\section{a. Green facade}

The support system has two main components, the planter and the structural support. The planter contains the growing media, while the structural support guides the plants upwards. Plants of the support system climbers are either grown directly from the ground adjacent to the building façade or grown from soil contained within modular planters. The location and size of the planter play an important role in the growth of the plant. The dimensions of the planter determine the amount of the space in which the plants can spread its roots into the soil. If plants are grown in modular planters, a minimum soil depth of $30 \mathrm{~cm}$ is recommended for healthy plant growth. To achieve a lush and even growth of greenery the planters can be located at various levels of the building (Chiang, 2009). Structural support types are classified as singular, mesh and surface panel. The choice of support types often depends on the species of the plants and the characteristic of their growing patterns. Some forms of support include steel wire cables and mesh, wooden trellis, fiberglass mesh, geo-textile for surface panels, etc.

\section{b. $\quad$ Living wall}

Carrier systems usually consist of pre-vegetated panels that are fixed vertically to a structural wall. These panels can be made of a wide range of materials including plastic, synthetic fabric, clay or metal and support a great diversity of plants (GRHC, 2008). There are three main components of the system namely, the growing substrate media, the carrier that holds the substrate media and its structure. The diversity of carrier sys tems that have been developed is a showcase of the creative design possibilities available for growing plants on the vertical surfaces. The differences in systems are governed by parameters such as aesthetics, profile thickness, weight, ease of maintenance, ease of construction, type of plants and cost (Cheng, 2010). Carrier systems can be further classified into two broad categories, namely horizontal and vertical. This is based on the plant/ substrate interface, which is the direction of the interface in which the plant is grown from the substrate media.

\subsubsection{Benefits of Vertical Greenery}

Vertical greenery helps to improve the overall environmental quality and serves as a solution to increase our contact with nature. The incorporation of vertical greenery provided benefits for a building and its occupants (private) as well as the city and the community at large (public). These benefits can be leveraged to sell or promote the technology, depending upon the intended audience (Peck et al., 1999). The architects, landscape architects or promoters of vertical greenery technology often have difficulties convincing their clients (i.e. the developer, policy makers and the general public) of its advantages and feasibility. There is generally a lack of knowledge of the benefits of vertical greenery other than its aesthetic appeal. The benefits of vertical greenery can be divided into three categories, namely aesthetic, environment and economic (Table 2) 
Table 2: Benefits of vertical greenery system

\begin{tabular}{ll}
\hline Category & \multicolumn{1}{c}{ Benefits } \\
\hline & - Greener skyline as part of city branding \\
- Visual relief from urban environment \\
- Enhance architectural designs, create iconic landmarks in the city \\
- Screen and isolate views \\
- Enhancing public spaces \\
- Reduction of the Urban Heat Island effect and regulating of the microclimate \\
- Improving the air quality by absorption of pollution and dust as well as reducing the \\
- Ereenhouse effect by CO ${ }_{2}$ absorption \\
- Improving rain water retention \\
- Therapeutic effects of plants and landscape \\
- Reduction of cooling loads through better insulation and shading \\
- Improving acoustic insulation \\
Economic
\end{tabular}

(Sumber: Hasil analisa, tahun)

\subsection{Methodology}

\subsubsection{Criteria for selection of articles}

Research studies on the vertical greenery system technology scan the beginning of the research published in academic papers from year 1999 to 2011 . To be included in this review, papers must meet the following criteria: (1) location of the study, (2) the findings apply directly to vertical greenery system technology; (3) the papers published in journals are peer reviewed or refereed conference papers influential, and (4) the papers published in English. If the paper is published as conference papers, they have been cited in peer reviewed journal papers, or represent the work of emerging topics. In other words, it has made a contribution towards knowledge is unique

\subsubsection{Method of analysis}

Research papers were collected and sorted by common research focus areas such as vertical greenery system, urban temperature, urban greenery, cooling effect, humidity, wind speed, urban heat island, vegetation, stormwater, energy, and plant or wildlife hab itat. All articles gathered from the online database that is Science Direct, Scopus, and Scribd. Only findings on vertical greenery system, cooling effect, temperature and humidity are presented here. Paper findings were summarized onto Table 1 to identify their original contribution to knowledge based on several factors including the type of vertical greenery system, location of the research, and significant findings of the study. If more than one design parameter was investigated in the paper, investigations were divided by separate design criteria and counted as separate investigation. As a result, a total of 21 articles were identified that are included in this analysis. Table 3 shows studies on definition of vertical greenery system by researchers. 
Table 3: Summary of vertical greenery system research sites by location and number of investigations

\begin{tabular}{lcl}
\hline \multicolumn{1}{c}{ Location of research } & $\begin{array}{c}\text { Number of } \\
\text { investigations }\end{array}$ & \multicolumn{1}{c}{ Reference } \\
\hline Thessaloniki, Greece & 3 & $\begin{array}{l}\text { Alexandri E and Jones P (2008), Eumorfopoulou E.A } \\
(2009), \text { Kontolen K.J (2010) }\end{array}$ \\
Ottawa, Canada & 3 & $\begin{array}{l}\text { Peck et al. (1999), Bass B and Baskaran B (2001), GRHC } \\
(2008)\end{array}$ \\
Brisbane. Australia & 3 & Birkeland J (2008, 2009) \\
Hong Kong, China & 2 & Cheng et al. (2010) \\
Singapore & 5 & Chiang K and Alex Tan (2009), Wong et al. (2010), \\
Delft, Netherland & 2 & Ottele et al. (2010), Perini et al. (2011) \\
Oxford, UK & 3 & Dunnett N and Kingsbury N (2008), Ip et al. (2009), \\
Totals & $\mathbf{2 1}$ & \\
\hline
\end{tabular}

( Source: Badrul, 2011)

\section{Result and Discussions}

Vertical greenery represents a new dimension in greenery-related infrastructure, where plants are incorporated within the vertical surfaces of buildings. While the idea itself is not new and a few countries have already conducted research and development into this area, vertical greenery has yet to be implemented on an extensive scale. Based on report GRHC (2008) stated that by given the large surface areas on buildings that available for retrofitting with these technologies, there is a great deal of latent potential worth uncovering by utilizing vertical greenery for positive environmental change in already dense urban areas. The report also investigated the potential of even a newer technology, vertical gardens, essentially moving the vegetation from the roof to the walls, in an urban environment. According to Bass and Baskaran (2003) vertical gardens could refer to vine covered walls, but they could also include additional infrastructure components to support the growing of vegetation on a wall or as part of a window shade. Both technologies were assessed using observations and modeling, and both were assessed with regards to the urban heat island and the reduction of indoor temperatures

Through review of 21 research and studies relating to vertical greenery system found that there are relevant factors such as panel size, structure and thermal absorption rate. This implicates there is a relationship between the factor of thermal, moisture, design and aesthetic. In research studies carried out at the University of Toronto since 1996, it has been proven that vertical greenery can reduce the heat flow into a building and that the surface temperature of vertical greenery is lower than that of a bare wall. Surface temperature observed in different settings at the University have consistently demonstrated that areas with vertical greenery are cooler than those with light-coloured bricks, wall and black surfaces that are typically found in urban areas (Bass and Baskaran, 2003). From the literature review related to vertical Greenery system (VGS), it appears that there is a lack of studies on aspects of VGS from heat and cooling effects to improve an environment conducive to building surfaces and surrounding areas.

The study conducted by Loh et al. (2008) and Cheng et al. (2010) focuses on the use of plants to reduce building heat. Wong et al. (2009) conduct a study solely to the thermal 
simulation and experimental calculation. Only Bass and Baskaran (2001) describe the potential use of vertical garden through the study of surface temperature and leaf surface. While Alexandri and Jones (2008) to study the thermal effect of the vegetation covering the building without taking in to account the aesthetic value. However, Wong et al. (2010) have carried out studies on vertical perception systems Greenery in Singapore to produce aesthetic value as a parameter study. His findings showed that all respondents were from the developer, consultant, government agencies and the resident agrees to the use of VGS to enhance visual interest. This study was supported by Peck et al. (1999) that plants can add visual interest to plain walls and roofs, industrial and commercial properties soften and allow a new building to blend in better with rural or suburban surroundings. Cheng et al. (2010) concluded that many factors such as physical structure, materials and dimensions of holding panels shall be conducted in the study of vertical greenery sys tem.

\section{Conclusion}

Today, the temperature rising in urban areas due to the replacement of natural vegetation with pavement, buildings and other structures. This scenario has influenced the building and the ambient temperature is higher than the green areas. Through tree planting, it can help to cool the building and surrounding area through shading, reduce the heat emitted and evapo-transpiration (Kelly and Tan, 2009; Cheng et al, 2010; Wong et al 2010). Vertical green system using plants grown on the surface of the building to reduce heat and large changes in temperature. It is cooler than the exposed concrete surface because most of the energy used to evaporate water rather than heat the surface and overlying air. Therefore, further studies on the role of the vertical greenery system to reduce heat and increase cooling effect should be given more attention, especially in relation to Urban Heat Island effect

\section{References}

Abdul M.A.R , Foong S. Y and Atikah F. A .2011. The Building Thermal Performance and Carbon Sequestration Evaluation for Psophocarpus tetrogonobulus on Biofaçade Wall in the Tropical Environment, World Academy of Science, Engineering and Technology 76 (2011) pp 86-94.

Alexandri E, Jones P. 2008. Temperature Decreases in an Urban Canyon Due to Green Walls and Green Roofs in Diverse Climates, Building and Environment 43 (2008) pp 480493.

Bass B., Baskaran B. 2001. Evaluating Rooftop and Vertical Gardens as an Adaptation Strategy for Urban Areas, Institute for Research and Construction, NRCC-46737, Project number A020, CCAF Report B1046, Ottawa, Canada, National Research Council.

Birkeland, Janis .2009. Eco-retrofitting with Building Integrated Living Systems. In: Proceedings of : the 3rd CIB International Conference on Smart and Sustainable Built Environment : SASBE09 : , 15 - 19 June 2009, Netherlands, Delft, Aula Congress Centre.

Birkeland, Janis. 2008. Challenging 'Best Practice' Subtropical Design. In: Subtropical Cities 2008 Conference - From Fault-Lines to Straight-Lines - Subtropical Urbanism in 2020, 3 - 6 September 2008, Australia, Queensland, Brisbane. 
Birkeland, Janis. 2008. Space Frame Walls : Facilitating Positive Development. In: The World Sustainable Building Conference 2008, 21-25 September 2008, Australia, Victoria, Melbourne.

Bonan G. 2002. Ecological Climatology. Cambridge: University Press. 2008. United State Environmental Protection Agency (EPA).Washington, DC 20460

Cheng C.Y, Cheung K.S and Chu L.M. 2010. Thermal Performance of a Vegetated Cladding System on Facade Walls, Building and Environment 45 (2010) pp 1779-1787.

Dunnett N and Kingsbury N. 2008. Planting Green Roofs and Living Walls. London: Timber Press.

Givoni B. 1998. Climate Considerations in Building and Urban Design. Canada: John Wiley and Sons.

GRHC. 2008. Introduction to Green Walls Technology, Benefits and Design. Green Roofs for Healthy Cities.

Kontolean K.J and Eumorfopoulou. 2010. Experimental Approach to The Contribution of Plant-Covered Walls to The Thermal Behaviour of Building Envelopes, Building and Environment 44 (2009) pp 1024-1038.

Kelly C and Tan A. 2009. Vertical Greenery for The Tropics. CUGE Research, National Parks Board, Singapore.

Loh, Susan and Stav, Yael. 2008. Green a City Grow a Wall. In: Proceedings of the Subtropical Cities 2008 Conference : From Fault-lines to Sight-lines : Subtropical Urbanism in 20 20, 3-6 September 2008, State Library of Queensland, Brisbane, Queensland.

Peck S.W., Callaghan C., Bass B., Kuhn M.E. 1999. Research Report Greenbacks from Green Roofs: Forging a New Industry In Canada Status Report on Benefits, Barriers and Opportunities for Green Roof and Vertical Garden Technology Diffusion. Canada Mortgage and Housing Corporation.

Perini K, Ottelé M, Fraaij A.L.A, Haas E.M, Raiteri R. 2011. Vertical Greening Systems and The Effect on Air Flow and Temperature on The Building Envelope, Building and Environment 46 (2011) pp 2287-2294.

Sternberg T, Viles H and Cathersides A. 2011. Evaluating the role of ivy (Hedera helix) in moderating wall surface microclimates and contributing to the bioprotection of historic buildings, Building and Environment 46 (2011) pp 293-297.

Ip K, Lam M and Miller A. 2010. Shading performance of a vertical deciduous climbing plant canopy, Building and Environment 45 (2010) pp 81-88.

Wong N.H, Tan A.Y.K, Tan P.Y, Kelly Chiang and Wong N.C. 2010. Acoustics Evaluation of Vertical Greenery Systems for Building Walls, Building and Environment 45 (2010) pp 411-420.

Wong N.H, Tan A.Y.K, Yu Chen, Kannagi Sekar, Tan P.Y, Derek Chan, Kelly Chiang and Wong N.C. 2010. Thermal Evaluation of Vertical Greenery Systems for Building Walls, Building and Environment 45 (2010) pp 663-672.

Wong N.H, Tan A.Y.K, Tan P.Y and Wong N.C. 2009. Energy Simulation of Vertical Greenery Systems, Energy and Buildings 41 (2009) pp 1401-1408.

Wong N.H, Tan A.Y.K, Tan P.Y.T, Angelia Sia and Wong N.C. 2009. Perception Studies of Vertical Greenery Systems in Singapore, Journal of Urban Planning and Development. Submitted August 3, 2009; accepted April 5, 2010; Posted head of print April 9, 2010. 